doi: $10.15503 /$ jecs2021.1.530.539

\title{
THE PRINCIPLE OF RULE OF LAW AND INDEPENDENCE OF THE JUDICIARY IN MYANMAR
}

\author{
NGE NGE AUNG \\ University of Debrecen, Geza Marton Doctoral School of Legal Studies, \\ Kassai út 26, 4028, Debrecen, Hungary \\ E-mail address: ngengeaung80@gmail.com \\ ORCID: https://orcid.org/0000-0002-3620-2849
}

\begin{abstract}
Aim. This research aims to discuss the importance of the principle of rule of law in protecting the judiciary's role, especially the independence of constitutional adjudication and its functions.

Methods. The study applies the case study approach and comparative method to investigate the constitutional court systems of some countries of the Association of Southeast Asian Nations (ASEAN) and their independence.

Results and conclusion. The resultsreveal a lack of the judiciary's independence, even among the top branches that are trying to implement democracy in Myanmar. The judiciary is under the control of the executive and legislature branches as their members belong to political parties. Moreover, a constitutional court is established with the members who are elected and nominated by the legislature and executive. Sometimes there can be conflicts when constitutional law does not mention the division of powers among governmental organisations like Myanmar, which results from the impractical functions of the Constitutional Tribunal of Myanmar.

Cognitive value. This research highlights possible ways to solve the constitutional issues among the three great branches. This initiative is in the interest of Myanmar citizens and citizens of all nations as these are international issues.

Key words: constitutional adjudication, the rule of law, judicial independence, interpretation, discretionary power
\end{abstract}

\section{INTRODUCTION}

$\mathrm{T}$ here is no exact definition delineating the independence of the judiciary's role. It is a concept widely recognised in every country where the citizens want to emulate a democracy. In this article, judicial independence is understood asthe judges and courts being free from the influence ofpolitical organs. This research intends to investigatethe separation of powers and the practical use of the powers divided between the executive, legislature, and judiciary.

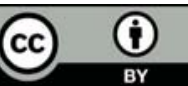


The doctrine of separation of powerswas formulated by the French scholar Baron Charles de Montesquieu, and it has been widely accepted in political science (Montesquieu, 1748/2001).

Under the separation of powers, nobody should simultaneously sit in more than one of the three great branches; that is, senators should not be judges or the President concurrently. In the same way, the President should not interfere in the legislation. Judges should neither be members of Parliament nor ministers at the same time. The three branches should not influence each other beyond the constitution's powers and duties.

\section{THE LATEST CONSTITUTION AND NEW CHALLENGES IN MYANMAR}

In Myanmar, the current constitution aims to implement amulti-party democratic system; however, it has several weak points. The two former constitutions are the Constitution 1947 and the Constitution 1974. The former was the first constitution after Myanmar gained its independence and the latter was formulated by the socialist system. Under the present constitution, Myanmarfaces many challenges and difficulties, whileordinary laws can be easily changed. Laws, rules, and regulations after 2008 are amended, and some old ones are repealed. However, the constitution itself cannot be changed (ZuluetaFulscher, 2020). Although there was no constitution implemented from 1988 to 2008 , the courts' composition and judicial system were altered twice in this time period.

The current constitution establishes that there are three different types of courts, and all are the supreme onesrespectively within their jurisdiction. The Supreme Court is the highest judicial organ, and it can supervise and give directions to the inferior courts. The Supreme Court's main function is to review cases alleging violations of the fundamental rights provided by the constitution. The Court Martial is only for military personnel who committed offences when they were on duty or under any other circumstances (Myan. Const. Sec294 and 319).

This distinct Constitutional Court system was established initially in civil law countries. But nowadays, the common law and civil law systems are mixed, and some common law countries, including Myanmar, are practising this style of court. The original intention behind building this court system is to protect the constitution, and the Constitutional Courts are precisely recognised as the guardians of the Constitution (Vinx, 2015). However, in Myanmar, the military has been vested with the power of guardianship over the constitution, which may be viewed as strange under the separation of powers doctrine. Most of the world's countries prescribe that the judiciary, like the Constitutional Court or Supreme Court, is responsible for safeguarding their constitution. 


\section{SEPARATION OF POWERS}

The Constitution 2008 mentions the possible way of division of powers, which is, however, vague.Union's legislative power is shared between the Pyidaungsu Hluttaw (Parliament), Region Hluttaws (legislative organs in each Region), and State Hluttaws (legislative organs in each State) (Myan. Const., sec 12(a)). According to the constitution, is divided by the Union territory into seven Regions and seven States.

The executive poweris shared between the Union and fourteen territories of Myanmar.The different layers of the state's courts have been vested with thejudicial power of the Union (Myan. Const., sec 17(a) and 18(a)).

\section{CONSTITUTIONAL ADJUDICATION}

A separate constitutional court system started in Austria, which aimed at verifying whether the actions of the executive and legislative bodies are constitutional or not. The idea of furnishing the Courts allows the judiciary's role to be independent ofthe other two branches. The Courthas also the competenceto hear cases on the misuse of power by authorities.

Nowadays, this style of court is widely accepted in Central Europe, Africa, and Asia. In South East Asian countries, several examples of this court system are the Constitutional Tribunal in Myanmar, the Constitutional Court in Thailand, the Constitutional Council in Cambodia, the Constitutional Court in Indonesia and others. Even though the names are different, their tasks are to protect and safeguard the constitutions promoting democracy and human rights.

In Thailand, the Constitutional Court tried the Prime Minister, Yingluck Shinawatra, with charges of the abuse of power vested in her by the people, ultimately dismissing her from the Prime Minister's position. In Indonesia, the Constitutional Court achieved success in solving the violation of human rights cases as several kinds of different national races live there. Their methods of solving the problems of human rights cases are becoming more helpful with each passing day, and the people rely on the functions of the Constitutional Court.

In Myanmar, the Tribunal has not been vested with the power to hear human rights cases. Instead, its primary functions are to interpret the constitution and to rule on the constitutional disputes, which may arise at the different levels of the executive and legislative organs of the state and other matters prescribed by any law (Nwe, 2016). In fact, the Court has less power and fewer functions than others all over the world. It may be concluded that the country's condition is among the least developed countries and its rule of law is incomplete because of poor economic conditions, social standards, and education systems in that country. These aspects may be related to each other, meaning the improvement of one condition could result in the improvement of another. 
Under the Constitution of 2008, the Tribunal was established mainly on the basis of the Kelsenian Court model, which originated in Austria and whose role was to interpret the constitution and decide the constitutional disputes among the state organs' authorities (Aung \& Lwin, 2015).

The Tribunal is composed of nine members, including the chairperson (Myan. Const.,sec 320). The executive nominates three Tribunal members, while the Lower House and Upper House of the legislature three members respectively (Con. Tri. Law of 2010, sec 3 and 4(a),(28 October 2010)).

The allocation of the nomination right to the judiciary cannot be found anywhere in the constitution, unlike the legislature and the executive. This is one of the weaknesses of the constitution: the independence of the judiciary isnot taken into consideration, even in theory, and as a result, it is not peculiar forthe judges of the Constitutional Court to bestruggling with the difficulties in their practice. Such challenges may be expectedcept in both near and distant future.

\section{METHODS OF INTERPRETATION: INTERNATIONAL AND REGIONAL APPROACH}

The main function of the Tribunal is to interpret the provisions of the constitution.The courts in Myanmar practise two methods of interpretation. The first method is a direct interpretation as prescribed in the provision and the second is taking into consideration the original drafters' or legislature's intentions.Moreover, the discussions, drafts, and records ofthe process of the law's creation can be taken into accountwhen a provision of the constitution is interpreted (Inter. of Exp. Law of 1973, sec 4, (5 December 1975)). This method is based on the traditional, English common law (Ducat, 2009). Therefore, the two uniform interpretations in the international application of laws are originalism and textualism.

Originalism occurs when an interpretation is based on the legislature's intention; it is also known as the traditional interpretation.It could be traced backto a landmarkcasein the USbetween two Americans of different skin colour. The black American claimed an equal right in education as white Americans. But the Supreme Court did not recognisethe plaintiff's equal right they claimed because the legislature's intention was taken into consideration. It can be concluded that the judiciary was not independentofthe influence of the legislature in interpretation (Plessy v. Ferguson,163 US 537 (1896)).

Textualism can be defined as a method of judicial interpretation,in whichdiscretionary powers are used beyond the legislature's influence and the traditional way. Otherwise, states that intend to exercise the democratic practicewouldstill have difficulty in achieving the goal of democracy. By focusing on the people's desires and not on the control of the authorities, the system of democracy is improved. After realising the disadvantages of tyranny, most states avoid itand accept the freedom of the people. 
Therefore, the interpretation process in common law countries should be based on the judges' discretionary power, and the judiciary should be given independence on the basis of the country's constitution rather than through the will of the legislature. Only the judiciary can protect the citizens' interests through the interpretation process when there is no exact provision in a constitution related to a certain matter. A legislature can make laws and the executive can confirm laws enacted by the legislature. The practical use of those laws always depends on the application of the judiciary for the benefit of the citizens.

\section{THE JUDICIAL WEAKNESSES IN MYANMAR IN COMPARISONTO SELECTED ASEAN COUNTRIES}

In Myanmar, the Tribunal's resolutions are final and conclusive, causing a lasting effect on the concerned government departments (Con. Tri.Law of 2010, 21 SPDC sec 23 (2010)). However, this goal was not case between the legislature and the Tribunal that occurred in 2012. A question was presented to the Tribunal to interpret the following:whether the committees and commissions formed by the Lower House are union level or not?

After citing relevant laws and sections, the Tribunal held that the committees and commissions formed by the Lower House are not Union Level. Although the constitution provided that the resolutions of the Tribunal are final and conclusive, the Parliament was not satisfied with this resolution, resulting in the majority ofthe Parliament impeaching the Tribunal's judges(Union'sPresidentv. Speakers of the Upper and Lower Houses, LR 2012 Con. Tri., (28 March 2012)). This case showed that the rule of law did not exist among the government's highest organisations.Even though the resolutions of that Court were supposed to befinal and conclusive, the legislature memberswho were not satisfied with the Tribunal's holding, managed to impeach all nine members of the Constitutional Tribunal.

Nowadays, the rule of law is recorded and obeyed among the authorities first and it is then promulgated to the people who understand its meaning through their Heads of the States. Why did the 2012 case in Myanmar proceed in the manner described above and why did the conflict between the Tribunal and the members of the legislature (Hluttaws in Myanmar) arise?

All nine members were removedresigned from the Tribunal because they did not want to amend or repeal the resolution as the current Constitution of 2008 officially explained that the Court's decision was final and conclusive. They believed the concerned authorities should respect each other and obey the fundamental law they passed. If they did not mutually respect the rule of law and chose to ignore it, then theTribunal's role as the guardian of the constitution would decrease in value, rendering the constitution to just a book and nonbinding law.

Therefore, rule of law is essential among the Heads of the States. Additionally, the separation of power and need to be preserved. Only after undertaking such measures will the fundamental rights, determined as human rights in 
the constitution, be safe for the citizens to enjoy them freely. This is an area in which Myanmar is currently struggling.Hence, this research attempts to figure out the best ways to promote the Constitutional Tribunal's functions through a comparative study.

After that, the Parliament amended some provisions of the Constitutional Tribunal Law of 2010 and changed the sequence of Sections 24 and 25. The takeaway is that the case led to a constitutional crisis. The constitution itself cannot be amended because of its strict requirements that $25 \%$ of the legislature is from the Military. Their votes are essential to get the majority vote of over $75 \%$ to amend some important sections of the constitution.

Therefore, from the British period to the present, the judiciary in Myanmar cannot be seen as independent from the other two branches. This is an exceptional period after gaining independence byMyanmar. Under the socialist ruling, the judiciary's role was completelyunder the control of the executive and legislature.

In Indonesia, the judiciary is independent and possesses the ability to enforce laws(Indo. Con of 1945, art 24(1)). The Constitutional Court is composed of nine people. The ordinary highestcourt, the People's Representative,and the President nominate each three of them (Indo. Con of 1945, art 24(c)).

In Thailand, members of the Tribunal consist of nine at a maximum and all of them are nominated by the judicial organs (Thai. Con of 2007, art 200). Thus, the Judiciary has the unique opportunity to nominate the members of the Constitutional Court. It has a significant competence in the impeachment process; for example, the former Prime Minister,YingluckShinawatra,was removed in 2014 by the decision of the Court as she abused theState's power as a supreme executive official for her personal affairs.

Those courts are assigned different functions thatgive thempower to promote democracy and human rights. The Constitutional Court in Thailand has the right to examine the Prime Minister's abuse of state authority. Also, the Court has the right of constitutional review to promote the rule of law. In Indonesia, the Constitutional Court is reliable and working because human rights cases are presented to the Court,whilethe Court remainsindependent of the influence of the other branches. Summing up, in South East Asia, courts are knownfor their independent functions.

In Europe, the Venice Commission on Constitutional Justice aims to promotenot only democracy but also human rights and to achieve the rule of law (World Conference on Constitutional Justice, 2017).

The Supreme Court of Myanmar has the right to issue writs when the citizens' fundamental rights are violated by the actions of the executive and legislature (Judi. Law of 2010, 20 SPDC, sec 16(a), (28 October 2010)). That is why individuals in Myanmar cannot present constitutional disputes to the Constitutional Court directly, but they can submit them through the representatives they elected (Nwe, 2016).

At present, those who took part in writing the constitutionmight have intended for the judiciary to be independent ofthe influences of the other two 
branches and established the separate Constitutional Court in 2011 but the separation of powers is not working in Myanmar in practice, as it is evidentfrom the above-mentioned case. So, the checks and balance system needs to be respected by state authorities and rule of law, widely recognised by modernized countries, yet itneeds to be observed as well. Then, fundamental law, also known as constitutional law, should be flexible enoughto be amended whenever necessary in order to maintain harmony and be capable of responding to the changing situations and solving constitutional conflicts.

In order toimplement the constitutional democracy, bearing the rule of law in mind isa requirement andthe authorities of the three great branches should respect each other. Otherwise, the citizens will not trust theactionsof theirgovernment.Suppose the above-mentioned constitutional values are not obeyed. In that case, the judiciary's role to safeguard the constitution and its citizens' fundamental rights might not be reliable at all. How can the judiciary stand independently from the influence of the other branches then?

\section{DOES DISCRETIONARY POWER BELONG TO THE JUDICIARY IN MYANMAR?}

Reviewing the above-mentioned case in Myanmar (2012), the separation of powers, the checks and balance system, and the courts' discretionary powerin common law countries have influenced the legislature. The constitution's task is to settle constitutional disputes between the executive, legislature, and judiciary. The judiciary is vested with the power of judicial review to interpret the constitution. In the past, Supreme Courts could interpret constitutions. The separation of powers under the Constitution in Myanmar is important to follow as the Revolutionary Council occupied Myanmar in 1962 and the judiciary was expressly under the influence of the other branches until 2008. However, some scholars accept that the separation of powers is not particularly related to judicial independence (Lowndes,2016).

First of all, the judiciary must be liberated from the predomination of politics.The core of judiciary's independence was not present during the kings' regime, except that the king was fair and kind-hearted. As only the kings possessed all authority in the land, sea, and air, they could influence everything and everyone in that period.

In Myanmar, the doctrine of separation of powers was repealed after the Revolutionary Council had taken over state power in 1962. The Chairman of the Revolutionary Council barred the previous independence of the judiciary throughout the state power. However, under the Constitution of 2008, the separation of powers doctrine has been utilised to implement democracy and to access the rule of law.

The doctrine of the separation of power cannot be seen in the appointment of the Tribunal judges. More significant numbers for the Tribunal are nominated by the Lower House and Upper House speakers. The executive can also 
appoint three members. However, the judiciary has no power to appoint any Tribunal members (ICJ(2014, March 18) Myanmar: Appointment and promotion of judges; Security of tenure). The most important pointis that the judges nominated by the legislature and executive are responsible to them. It shows that the judiciary is still under the improper influence of other branches (Law Amend.Con. Tri. of 2013, sec 12 (2013)).

Although the Tribunal can check whether the actions of the executive and legislature are constitutional or not due to the checks and balance system,Myanmar citizens can claim a legal remedy only directly to the Supreme Court and not to the Tribunal if their fundamental rights in the constitution are infringed (Aung, 2020).

The Tribunal's taskis to resolve constitutional disputes betweenthe Union and local'sinstitutions founded by the current constitution.The ambitions to promote democracy and human rights are not assignedto the Tribunal's functions, unlike in other civil law countries. Statutory interpretation is to follow the provisions of the constitutional law (Myan. Const., sec 453).

Statutory laws shall be citedby the courts and judges in their decision-making. Since laws are codified and then applied practically,they require frequent updates in line with the social needs under the current system and the public interest. In common law countries, thediscretionary powers of the judges are important in making judgments, not just the statutes. In Myanmar, the Interpretation of Expression Law of 1973 has to be followed in decision-making, which is akin to systems in other common law countries. This law seems to prohibit the independence of the judiciary.

According to the US Chief Justice John Marshall, “Judicial power, as contradistinguished from the power of the laws, has no existence and it is just legal discretion if appropriate" (1803).

But it is rare to hear of the judiciary actingultra vires against the other two branches. Most of the cases occur when the executive or legislature is tryingto influence the judiciary. Throughout the world, the judiciary is always less powerful than the legislative and executive branches. Therefore, many scholars have written about how the judiciary is under the undue influence of politics and they are seeking possible solutions to reconcile among the governmental organisations.

Even though most of the countries in the world accept that constitutional courts or tribunals have the duty to safeguard and protect the constitution, in Myanmar it is the military who has the commitment to preserve the officially providedconstitution (Myan. Const., sec 20(f)). 25\% of Parliament's members are from the military. Therefore, it is challenging to amend the constitution because of the military's abnormal participation in politics. The constitutional requirements'sneeds are difficult to be performed unless $25 \%$ of the military personnel agree, andthis is also a noticeable influencebeyond the separation of powers.

In 2011, the executive tried to influence the state's judicial power by seeking permission for 27 administrators to serve as the first-class power magistrates in 
the subdivision. The Supreme Court of the Union, which is the supreme judicial organ, can supervise inferior courts. It submitted a reference to theTribunal to interpret it in line with sec 293 and sec317 of the Constitution.The judicial power was vested into the administers to decide criminal cases under the control of the Department of General Administration awarding them summary trial power (Htay, 2021).

The Tribunal held that it is inconsistent with constitutional law because state powers shall be shared between the executive, legislature, and judiciary under the constitution's fundamental principles. Additionally, judicial powers have been vested to the judges on the different levels of the courts.

It is evident that the executive wanted to influence the judiciary as before. In prior times, the separation of powers was unclear and the administrators who had been appointed in the remote areas were vested with the judicial power to decide casesconcurrently.

\section{CONCLUSION}

The separation of power - the concept of French legal scholar Montesquieu - is necessary in both legal theory and practice. Especially in developing countries, such asMyanmar, the constitution is the fundamental law and the powers and duties of the legislature, executive, and judiciary should be clearly prescribed to avoid ambiguity. Otherwise, allocations of powers and constitutional reasoningsshould be granteddemocratically. If Myanmar exercised real democracy, there would be fewer constitutional problems among its government organisations. Further, the constitution would become more flexible. In the US, a 'semi' separation of powers is exercised, and it cannot be defined as a complete one. The judiciary could stand independently under the case of Marbury v. Madison, which was decided in 1803 and established the concept of judicial review.

In conclusion, the judiciary needs to be independent in practising its duties and responsibilities from the executive's and legislature's influence, even though the constitutional provisions onthe separation of powers are incomplete. One of the executive'sand the legislature's essential responsibilities is to support the judiciary machinery since the laws, rules, regulations, and orders that are enacted provisionally by those branches have to be implemented by the judiciary for the public interest. No man or institution should be above the law.Therefore, the rule of law iscrucialfor both the government and the governed, who need adequate protection within the legal framework. 


\section{REFERENCES}

[1] Aung, M. K. S. (2020). Writ Jurisdiction in Myanmar, Dagon University Research Journal, 11, 98-105. Retrieved June 11, 2020, from https://www.dagonuniversity.edu.mm/wp-content/ uploads/2020/05/13.-Mi-Khin-Saw-Aung-1.pdf.

[2] Aung, N. N. (2013). Comparison on Formation of Courts between Myanmar and IndiaConstitution. Taunggyi University Research Journal,4(1), 54-62.

[3] Aung, N. N., \& Lwin, S. S. (2015). Comparison on Formation of Courts among Some ASEAN Countries [Unpublished research project]. Department of Law, Taunggyi University, Myanmar.

[4] Brown v. Bd. of Educ. 347 U.S. 483, 74 S.Ct. 686(1954).

[5] Bur. Const. of 1947.

[6] Bur. Const. of 1974.

[7] Chemerinsky, E. (2015). Constitutional Law: Principle and Policy, New York: Wolters Kluwer.

[8] Const. Tri. Law of 2010.

[9] Const. Tri. Amend. Law of 2013.

[10] Council of Europe (2014). World Conference on Constitutional Justice. Retrieved March 14, 2021, fromhttps://www.venice.coe.int/WebForms/pages/?p=02_WCCJ.

[11] Daw, H. M. N. (2016). Developments in Myanmar Constitutional Law: The Year 2016 in Review, International Journal of Constitutional Law, I-CONnect Blog. Retrieved May 7, 2020, from http://www.iconnectblog.com/2017/12/ developments-in-myanmar-constitutional-law-the-year-2016-in-review/.

[12] Ducat, C. R. (2009). Constitutional Interpretation,Canada: Wadsworth, Cengage Learning.

[13] Gov. of Bur. Act of 1935.

[14] Htay, C. M. (2021, Jan 14). Challenges of the Independence of the Constitutional Tribunal in Myanmar [Conference Session], Judicial Independence in ASEAN: A Comparative Perspective, Nagoya University (CALE). Retrieved March 24, 2021, from https:/cale.law.nagoya-u.ac.jp/ index-eng.

[15] Indo. Const. of 1945.

[16] Int. of Exp. Law of 1973.

[17] International Commission of Jurists. (2014). Myanmar Appointment and Promotionof Judges; Security of Tenure. Retrieved June 2, 2020, from www.icj.org.

[18] Lowndes, J. (2016). Judicial Independence and Judicial Accountability at the Coalface of the Australian Judiciary. Retrieved March 13,2021, from https://localcourt.nt.gov.au/sites/ default/files/judicial_independence_and_judicial_accountability_at_the_coalface_of_the_ australian_judiciary_.pdf.

[19] Marbury v. Madison, 5 U.S.(1Cranch) 137(1803).

[20] Montesquieu, Baron Charles de (2001). The Spirit of the Laws. (T. Nugent. Trans). Ontario: Batocle Books. (Original work published 1748).

[21] Myan. Const. of 2008.

[22] Plessy v. Ferguson, 263 US 537 (1896).163 U.S 537, 16 S. Ct. 1138 (1896)

[23] Pyithu Hluttaw v. the Members of the Constitutional Court of the Union, (2012). Reference 1: 1-23. Retrieved March 15, 2021, from https://www.constitutionaltribunal.gov.mm/my/ publication $/ 32$

[24] Thai. Const. of 2007.

[25] Uni. Judi. Law of 2010

[26] Vinx, L. (Ed.). (2015). The Guardian of the Constitution: Hans Kelsen and Carl Schmitt on the Limits of Constitutional Law. United Kingdom: Cambridge University Press.

[27] Zulueta-Fulscher, K. (2020). Looking back at the Myanmar Constitution amendmentprocess. Retrieved July 5, 2020, from www.idea.int. 